\title{
Cafemodellen: \\ Anerkendende feedback i projektgrupper
}

\author{
Lene Tortzen Bager, lektor, Center for Undervisningsudvikling, Aarhus Universitet
}

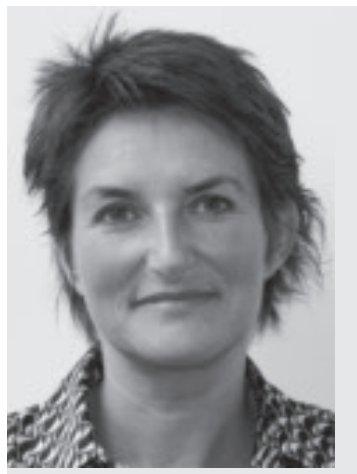

Lene Tortzen Bager er tidligere lektor ved Institut for Æstetiske Fag, AU, hvorfra hun har undervisningserfaring fra æstetik- og kultur-faglige forløb og forskningsbaggrund inden for samtidskunstens teori, historie og reception. Siden 2008 er hun ansat som lektor ved Center for Undervisningsudvikling, hvor hendes forsknings- og udviklingsopgaver vedrører universitetspædagogik, involverende undervisningsformer, entrepreneuriel didaktik, kollegial supervision, vejledning og feedback.

Kan feedback på meningsfuld måde varetages af de studerende selv? Kan de studerende loere at anvende feedbackformer, der kvalificerer dem til at indgå i fagligt larende fallesskaber? I artiklen beskrives erfaringer med at lade studerende give hinanden feedback gennem cafemodellen i forbindelse med projektarbejde. Den padagogiske hensigt hermed er, at de studerende fär erfaring med en anerkendende tilgang, med at anvende dialogens lytte- og tale-positioner aktivt samt med at konstituere sin rolle som studerende $i$ et larende fallesskab.

\section{Introduktion}

Cafemodellen er en feedbackform, jeg har eksperimenteret med i forbindelse med udvikling af et nystartet undervisningsforløb på kandidatuddannelsen i Oplevelsesøkonomi ved Nordisk Institut, Aarhus Universitet i 2007. I denne artikel beskriver jeg principperne bag cafemodellen, ligesom jeg gennemgår selve metoden $\mathrm{i}$ modellen og erfaringerne med at anvende modellen.

\section{Hvad er principperne bag cafémodellen?}

I cafemodellen anvendes en samtalemodel, som bl.a. kendes fra coaching, kollegial supervision og fra reflekterende teams. ${ }^{1}$ Modellen kan bruges i forbindelse med gruppearbejde og er særligt velegnet, når der er tale om længerevarende projektarbejde, hvor samtalerne kan hjælpe med at afdække og fastholde faser i processen.

Modellen beskriver tre roller eller funktioner i en systemisk samtale, hvor hver projektgruppe på skift varetager en funktion i samtalen:

- Fokusgruppen har viden og ressourcer

- Supervisionsgruppen hjælper med at uddybe og konkretisere fokusgruppens emne gennem en anerkendende tilgang

- Iagttagergruppen lytter aktivt, tager notater, samler op og beskriver samtalens forløb

Den systemiske teori, som denne samtaleform bygger på, betoner, at den enkeltes handlinger og holdninger sker i et fællesskab, som er en betydningsgivende kontekst. Ændres et led i fællesskabet, ændres hele fællesskabet; og teorien vægter denne mulighed for forandring. Samtalen er desuden baseret på en anerkendende tilgang, Appreaciative Inquiry, som tager afsæt i, at den enkelte har ressourcer, viden og færdigheder, som kan komme til udtryk gennem en anerkendende og undersøgende samtale. I forhold til cafemodellens roller betyder det, at fokusgruppen har viden og ressourcer, som supervisionsgruppen kan hjælpe med at uddybe og konkretisere gennem anerkendende og åbent undersøgende spørgsmål i en samtale, som iagttagergruppen lytter til, samler op på og skaber perspektiv i. Tankesættet bag den anerkendende tilgang tager således udgangspunkt $i$, at den anden gennem refleksion og undersøgelse af erfaringer kan blive klogere på betydninger, viden og muligheder. At tilgangen i samtalen er anerkendende betyder ikke et fravær af en traditionel kritisk (akademisk) diskurs, men en kritisk diskurs, der formuleres gennem anerkendelse og undersøgelse. Kritiske synspunkter kan formuleres positivt som undersøgende og afdækkende spørgsmål, som f.eks. «Hvad ville det gore ved Jeres idé, hvis I...?" 
Denne case er et eksempel på den opgave, som grupperne fik efter en introduktion til cafemodellen. Casen startede gruppernes arbejde med cafemodellen.

\section{Case: Konstruer en kollektiv identitet for gruppen}

Baggrund: De studerende har ved studiestart oploadet individuelle portrætter af sig selv med beskrivelse af faglig baggrund, interesser og begrundelse for deres valg af kandidatuddannelsen i Oplevelses$ø$ konomi. Herefter er de studerende af lærergruppen blevet inddelt i projektgrupper, og denne første cafe har til formål at understøtte gruppens proces med at etablere en gruppeidentitet.

Holdet er på dette tidspunkt blevet introduceret til cafemodellen og har prøvet den i ultrakorte samtale-runder.

Instruktion til øvelsen:

I skal konstruere en kollektiv identitet for Jeres gruppe: hvorfor er I en gruppe? Hvad er Jeres gruppes omdrejningspunkt? Hvorfor er dette Jeres omdrejningspunkt? Jeres diskussioner og undersogelser skal udmontes $i$ et navn til gruppen og et slogan for gruppens identitet. I skal beskrive baggrunden for gruppens navn og slogan $i$ et dokument, som I oploader i den elektroniske konference. For noste undervisningsgang, hvor vi arbejder med cafemodellen med tre deltagende grupper, som skiftes til at agere $i$ rollen som henholdsvis fokusgruppe supervisionsgruppe og iagttagergruppe, har I til opgave at scette Jer grundigt ind $i$ hinandens dokumenter. Pa cafeen skal den enkelte projektgruppe vere forberedt på at prosentere gruppens identitet mundtligt for de to andre grupper $i$ cafeen $i$ ca. 10 minutter, herefter vil den gruppe, der fungerer som supervisionsgruppe, sporge undersogende ind til afklaringsprocessen, betydningen af navn og slogan for gruppeidentiteten mv., denne samtale varer max 25 minutter. Derefter har iagttagergruppen til opgave at samle op pa samtalen, beskrive dens dynamik og pege på perspektiver i samtalen, så fokusgruppen fär noget med tilbage at reflektere over. Opsamlingen varer max 10 minutter.

Efter en runde på $i$ alt 45 minutter skifter grupperne roller $i$ cafemodellen og fortscetter runden, indtil alle grupper har provet alle roller.

\section{Hvordan gennemføres cafemodellen i praksis?}

Som nævnt tildeles hver projektgruppe forskellige roller undervejs i forløbet. Nedenfor beskriver jeg de tre forskellige roller, som grupperne varetager på skift.

\section{De tre gruppers roller og samtalens proces}

Fokusgruppen præsenterer sit emne i 10 minutter. Herefter besvarer gruppen spørgsmål fra supervisionsgruppen. Fokusgruppen deltager i dialogen med supervisionsgruppen i overensstemmelse med det fælles forarbejde, ligesom fokusgruppens medlemmer undervejs lytter til hinandens svar. Det er ikke tilladt at underkende hinandens idéer eller at fastholde egne kæpheste. Hvis der opstår uenigheder, gøres de til genstand for nye undersøgelser. Supervisionsgruppens rolle er at imødekomme fokusgruppens præsentation og emne med åbne spørgsmål, som kan hjælpe med at belyse og undersøge emnet yderligere. Det er supervisionsgruppens rolle at give fokusgruppen lejlighed til at udtrykke sig nuanceret og formidlende om dens arbejde, om processer heri samt om det aktuelle emne for cafeen.

Det er ikke tilladt at dømme fokusgruppens arbejde, udsagn eller at kritisere ukonstruktivt. Samtalen varer max 25 minutter.

Iagttagergruppens rolle er først og fremmest at lytte aktivt til dynamikken mellem fokusgruppen og supervisionsgruppen og tage notater til samtalens forløb, emner og spring. Hvilke spørgsmål virker øjenåbnende for fokusgruppen? Er der emner/områder, supervisionsgruppen overser? Hvilke ideer bliver forladt af fokusgruppen, og hvordan sker dette? Hvilke dilemmaer eller problemstillinger ser ud til at stå anderledes for fokusgruppen efter denne samtale? Iagttagergruppen samler op ved at beskrive og perspektivere samtalen i max 10 minutter.

\section{Timeout}

I gennemførelsen af samtalen kan man vælge at anvende en strategi, der hedder timeout. Strategien går ud på, at man aftaler et stop i samtalen, som kan bruges til at skabe klarhed over samtalens proces eller emne. Fokusgruppen kan eksempelvis anvende timeout til at bringe samtalen tilbage på sporet, hvis gruppen oplever, at samtalens fokus flytter sig for hurtigt. Eller supervisionsgruppen kan anvende timeout, hvis medlemmerne har brug for at meta-samtale om, hvilke emner de ønsker at undersøge nærmere. Supervisionsgruppen kan lave timeout for på et metaplan at drøfte med fokusgruppen, om samtalens proces eller emne er på et vedkommende spor. Desuden kan iagttagergruppen vælge at anvende timeout, hvis den ønsker at gøre supervisionsgruppen eller fokusgruppen opmærksom på, at den anerkendende tilgang ikke bliver håndhævet. Endelig kan grupperne på forhånd have aftalt at anvende timeout som redskab til metarefleksion i samtalen. Ellers spiller iagttagergruppen generelt rollen som den metareflekterende part i cafemodellen.

\section{Sporgeteknik}

Foruden timeouts er spørgeteknik og spørgsmålskategorier en nyttig hjælp i forståelsen af rollerne i samtalen og til at understøtte bevægelse og dynamik i samtalen. 


\begin{tabular}{|c|c|}
\hline $\begin{array}{l}\text { Lineære spørgsmål } \\
\text { Anvendes til at afklare } \\
\text { hændelser, årsager, facts. } \\
\text { Spørger er en art detektiv. } \\
\text { Spørgsmålstyper: } \\
\text { Hvad? } \\
\text { Hvor? } \\
\text { Hvornår? }\end{array}$ & $\begin{array}{l}\text { Cirkulære spørgsmål } \\
\text { Anvendes til at undersøge } \\
\text { adfærd, perspektiver, } \\
\text { kontekster evt. bagud } \\
\text { i tid. Spørger er en art } \\
\text { opdagelsesrejsende eller } \\
\text { antropolog, som undersøger } \\
\text { forskelle, perspektiver og } \\
\text { synsvinkler. } \\
\text { Spørgsmålstyper: } \\
\text { Beskrivende: Karakteriser } \\
\text { forskelle fra for ti år siden } \\
\text { til nu? } \\
\text { - Forklarende ud fra forskel, } \\
\text { perspektiv, synsvinkel: } \\
\text { Hvordan ville } X \text { opfatte } \\
\text { handlingen, som Q foretog } \\
\text { sig? }\end{array}$ \\
\hline $\begin{array}{l}\text { Strategiske spørgsmål } \\
\text { Anvendes for at fremkalde } \\
\text { en virkning, handling eller et } \\
\text { indblik Spørger er vidende } \\
\text { og foran i samtalen. } \\
\text { Spørgsmålstyper: } \\
\text { - Konfronterende: Hvor } \\
\text { meget må det koste at..? } \\
\text { - Opfordrende: Hvem } \\
\text { skal kontaktes for at få } \\
\text { oplysning om..? } \\
\text { - Ledende: Overvej, hvad du } \\
\text { vil prioritere, hvis..? }\end{array}$ & $\begin{array}{l}\text { Refleksive spørgsmål } \\
\text { Anvendes med henblik } \\
\text { på at skabe ny indsigt og } \\
\text { nye handlemuligheder, } \\
\text { fremadrettet og stimulerer } \\
\text { til refleksion } \\
\text { Spørger: undrer sig, } \\
\text { anerkender, coacher } \\
\text { Spørgsmålstyper: } \\
\text { Tidsmarkerende: Hvordan } \\
\text { ser dette ud, om et år - } \\
\text { og hvad er der sket i } \\
\text { mellemtiden? } \\
\text { Hypotetiske spørgsmål: } \\
\text { Hvis } X \text { siger ja, betyder } \\
\text { det så noget for P? }\end{array}$ \\
\hline
\end{tabular}

Figur I: Karl Tomms spørgsmålskategorier kan anvendes som inspiration eller som et redskab i cafemodellen.

Figur 1 illustrerer nogle spørgsmålskategorier, der kan anvendes som redskab til at styrke deltagernes opmærksomhed på at arbejde anerkendende og undersøgende i samtalen. Spørgsmålstyperne er udviklet af Karl Tomm og hviler på en systemisk tankegang i overensstemmelse med cafemodellens principielle grundlag.

\section{Erfaringer med at anvende cafemodellen}

Den konkrete ramme om mine erfaringer med cafemodellen er det forste hold studerende optaget på kandidatuddannelsen i Oplevelsesøkonomi ved Nordisk Institut, Aarhus Universitet i 2007. Holdet på 49 studerende har bachelorgrader fra humaniora, samfundsvidenskab, naturvidenskab, ASB, AAA, Designskolen samt udenlandske universiteter. Uddannelsen har til formål at give de studerende kompetencer til at kunne analysere, innovere og udvikle projekter inden for Oplevelsesøkonomien, som i denne sammenhæng forstås som en dynamisk kulturel samfundsmæssig ramme. Forløbet, som blev understøttet af cafemodellen, hedder Entrepreneurship - koncept og forretningsudvikling (10 ECTS) og ligger på uddannelsens første semester. Dette forløb i entrepreneurship er undervisning, som tager udgangspunkt i den studerendes faglige og personlige kompetencer og har som mål at transformere kompetencerne til objektive færdigheder, som skal gøre den studerende $i$ stand til at handle mulighedsorienteret $i$ en kontekstuel sammenhæng. Der er tale om undervisning, der har som læringsmål, at den studerende med en øget bevidsthed om sine faglige metoder og praksisformer kan koble sig på og samarbejde i flerfaglige projekter. Forløbet er skemalagt med en fast ugentlig undervisningsdag med tre timer, og undervisningen er tilrettelagt med henblik på høj grad af involvering af de studerende i selve undervisningstimerne såvel som mellem undervisningsgangene: Efter hver forelæsning ligger en øvelse, som de studerende besvarer i deres projektgruppe. Besvarelsen (8-10 sider) skal være oploadet $\mathrm{i}$ en elektronisk konference tre dage senere og være forberedt af cafemodellens deltagende grupper før den følgende undervisningsgang, hvor projektgrupperne modtager og giver hinanden anerkendende feedback. Besvarelsen af rækken af øvelser danner en portfolio, som er grundarbejdet i eksamensopgaven, der indleveres i projektgrupper og forsvares mundtligt.

\section{Instruktion og ovelse er vigtige elementer}

Fra første undervisningsforløb erfarede jeg, at cafemodellen kræver grundig instruktion. Det gælder beskrivelsen af rollernes funktion i samtalen og processen $i$ samtalen, og det gælder den anerkendende tilgang og de spørgeteknikker, der understøtter denne tilgang til forskel fra den traditionelt kritiske akademiske tilgang. Grundig instruktion er nødvendig dels for de deltagende projektgrupper, dels for det deltagende lærerteam. Instruktionen kan med fordel både udleveres som et handout med beskrivelse af samtalens tre funktioner og med spørgsmålstypologier, men hverken rolle eller spørgsmålstype kan læres som tekst eller teori; det er nødvendigt at praktisere og gøre sig erfaringer med rollerne for at forstå den enkelte gruppes funktion $i$ samtalen. I det aktuelle forløb var det især iagttagerrollen, der gav både studerende og undervisere stof til eftertanke. Vi oplevede, hvor stærk trangen til at ytre sig er, og hvor meget den skal tøjles, hvis dialogen med fokusgruppen ikke skal blive præget af tilfældige kommentarer. Det var utroligt lærerigt for både undervisere og cafedeltagere at opleve, hvor aktiv lyttepositionen er $i$ en samtale. I starten af det første forløb deltog lærerne $i$ en art refleksiv position i den enkelte cafe. Men det viste sig ikke at være hensigtsmæssigt, dels fordi lærerteamet selv var for uøvede i cafemodellens roller og samtaleteknik, og dels fordi opgaven jo allerede blev varetaget af iagttagergruppen. I stedet vil jeg anbefale, at cafemodellen instrueres grundigt gennem små øvelser med samtalemodellen, hvor der i plenum er lejlighed til at stille spørgsmål på baggrund af opstået tvivl og erfaringer. Efter bare få erfaringer med cafemodellen viste motiveringen af arbejdsformen sig ikke at være 
nogen stor opgave. Grunden var, at den enkelte gruppe oplevede at få feedback, der var meningsfuld og som gav konkrete anvisninger til en videre arbejdsproces.

\section{Cafegrupperne bor etableres fra start}

Det er en anden væsentlig erfaring, at cafegrupperne bør etableres fra starten, så de samme grupper mødes i cafeerne hen over semestret. Det giver mulighed for at se projekterne $\mathrm{i}$ en proces og for at give grundig feedback på såvel projektemne som proces og samarbejde. De studerende får oplevelsen af og erfaring med at være hinandens kompetente fagfæller.

\section{De studerendes evaluering af cafemodellen: Lærerigt men krævende!}

Brugen af cafemodellen skal naturligvis ses i lyset af de læringsmål og arbejds- og prøveformer, det enkelte undervisningsforløb er beskrevet gennem. I forbindelse med undervisningen i entrepreneurship udviklede vi cafemodellen for at understøtte de studerendes samarbejde på tværs af fag med processer som skal bevidstgøre dem om hver deres faglige og personlige styrker, om fagligt begrundede metoder og antagelser, og som skal styrke dem i deres handlekraft. Det var en vigtig udfordring at etablere en nysgerrig og tillidsfuld synsvinkel på de faglige forskelle mellem bachelorer fra vidt forskellige fakulteter og læringsmiljøer. Den anerkendende tilgang giver mulighed for at se forskelle som ressourcer og imødekomme fagligt forskellige antagelser med en undersøgende tilgang. Det er hensigten, at cafemodellens samtalepositioner fungerer som et redskab og en ramme, der gør de studerende i stand til at give hinanden feedback ud fra et anerkendende grundlag, der kan stimulere gruppernes dialog. Erfaringen fra anvendelsen af cafemodellen hen over semestret er, at den stort set fungerede efter hensigten. Og i forbindelse med den mundtlige eksamen blev det for alvor tydeligt for både studerende og undervisere, hvor meget den anerkendende tilgang og træningen i samtalens tale- og lyttepositioner havde styrket den enkelte studerende $\mathrm{i}$ forhold til at sprogliggøre processer, tage åbent imod spørgsmål og i sin dialog være sikker på at tage udgangspunkt $i$ egne faglige og personlige forudsætninger. Af den elektroniske evaluering af forløbet fremhæves cafemodellen også som et centralt element $i$ den enkeltes udbytte af forløbet. På det åbne spørgsmål Hvad loerte du mest af? Lyder nogle af svarene:

- Cafe-moderne. Det er i udvekslingen mellem de studerende, at der sker noget spandende og brugbart. Her kommer man til at reflektere over, hvordan andre uden for gruppen opfatter projekt og proces. Det er også her, man deler erfaringer osv.

- At vare del af en gruppe, som arbejder og forhandler sig igennem en proces og frem mod et koncept, hvor alle har kunnet bidrage. Cafemoderne har også varet gavnlige til at få nye perspektiver på ens projekt, dog har der måske varet lidt for mange af dem.

- Ved ikke, måske café-model - når de fungerede efter hensigten.

Som de sidste citater antyder, har i hvert fald er par studerende oplevet, at udbyttet af cafemodellen var svingende, og de studerende beskriver også ret grundigt i evalueringen, at de har oplevet forløbet som en overordentlig stor arbejdsbyrde. I arbejdsbyrden og det store arbejdspres ligger der imidlertid også et fagligt begrundet pres fra undervisernes side på de studerende for, at de skal forstå og erfare i en vedvarende interaktion, som involverer og påvirker den enkelte personligt og fagligt, samtidigt med at de driver et projekt frem. Det vil sige, at mens de studerende arbejder på højtryk i deres projektgrupper, oplever de at yde med nogle kompetencer og sider af sig selv, som de ikke har prøvet før. Og de oplever at dette bidrager til at skabe en anden type undervisningsmiljø, end de med meget stor sandsynlighed har mødt før. ${ }^{2}$

\section{Perspektivering - læring $i$ et fagligt praksisfællesskab}

Det er en erfaring fra anvendelse af systemiske og anerkendende samtaler i forbindelse med kollegial supervision blandt undervisere ved Humaniora på AU, at underviserne oplever at få redskaber, som de kan anvende i undervisning og vejledning. ${ }^{3}$ Derfor har det været en enkel manøvre at fortsætte tanken: Hvis samtale er et vigtigt redskab for underviserne $i$ undervisningen og det kollegiale samarbejde, kan samtale så ikke også blive det for de studerende i deres faglige samarbejde? Det, der har interesseret mig i eksperimentet med cafemodellen som feedbackform, er spørgsmålet om, hvordan vi gør de studerende i stand til at spille en tydeligere rolle for hinanden som kompetente deltagere i et fagligt fællesskab? Grunden til spørgsmålet er, at jeg dels som underviser selv oplever, at underviseren tillægges meget stor betydning af de studerende, og at jeg dels hører andre undervisere fortælle om den samme erfaring. Nogle studerende udtrykker direkte, at de foretrækker at høre underviseren frem for deres medstuderende, at de er usikre på hinandens kunnen og dermed bliver det vanskeligt for de studerende at håndtere arbejde på egen hånd og samarbejde i grupper. Der kan være flere grunde til, at underviseren står så centralt for de studerende. En af forklaringerne på de studerendes ønske om mere tid med underviseren kan være deres behov for at lære igennem iagttagelse af faget i praksis, dvs. at fă lov til at se underviseren agere i faget. Så hvis vi ønsker at styrke de studerendes mulighed for at lære mere bredspektret og styrke deres kompetence til at agere kompetent over for hinanden, så skal vi styrke de studerendes mulighed for at praktisere fagligheden og gøre dem i stand til at forholde sig til hinanden som 
dele af et lærende fællesskab. Cafemodellen beskriver en aftalt form på samtalen, som rammesætter tale og lytte-positioner og giver redskaber $i$ form af spørgsmålskategorier. De studerende øver sig $i$ at forpligte sig $i$ et lærende fællesskab, hvor det ikke er underviseren, men de studerende selv, der har hovedrollen. De lærer at agere $\mathrm{i}$ faget ved selv at agere.

\section{Noter}

1 Cafemodellen kan minde om cafemetoden, som er en udbredt metode til at understøtte videndeling i grupper og et anerkendt værktøj til at facilitere gruppeprocesser. Cafeen indrettes ved borde, der har 3-6 "gæster« og en "vært«, som drøfter et fastlagt tema.Værten kan invitere nye gæster til at deltage i diskussion fra tilstødende cafeborde.

2 I kombinationen af foretagsomhed som et specifikt entrepreneurielt læringsmål og cafemodellens systemiske og anerkendende samtale, ligger der stof til en dybere diskussion af læringsteoretiske tilgange til udvikling af undervisningsformer på universiteterne. Det er en omfattende og spændende diskussion, som har jeg bl.a. har taget hul på med Per Blenker i artiklen "Bevidsthed om læring - en kompetence med udgangspunkt $\mathrm{i}$ entrepreneuriel undervisning", i Arbejdspapir nr. 1, 2008, Center for Undervisningsudvikling, AU. Artiklen ligger i elektronisk version på www.cfu.dk

3 Leth Andersen og Søndergaard, 2007: Kollegial supervision på universitetet, Aarhus Universitetsforlag. 